\title{
Changing Ideas and Promoting the Transformational Development of Local Undergraduate Colleges and Universities
}

\author{
Feng Gao ${ }^{1,}{ }^{*}$, Qingling $\mathrm{Qu}{ }^{2, \mathrm{~b}}$ \\ ${ }^{1}$ Physics College, Baicheng Normal University, Baicheng,137000,China \\ ${ }^{2}$ Physical Education College, Baicheng Normal University, Baicheng,137000,China \\ aemail:gaof317@163.com, bemail:quqinglingkuaile@126.com, "corresponding author
}

Keywords: Transformational Development, Local College and University, Changing Ideas, the University-Enterprise Cooperation

\begin{abstract}
Under the current background of structural adjustment of national higher education, the transformation from local undergraduate colleges and universities to technical applied undergraduate universities is the key of the success of education reform. The primary task of transformation is changing ideas, the governments, local colleges and college students need to change the old narrow ideas and enhance the understanding of transformational development of local colleges and universities. Only establishing a new idea, correctly understanding the meaning and function of transformation, can we ensure that the process of transformation and development of local colleges and universities is smooth and stable. It was studied to ensure the success of the transformational development that why and how to changing the ideas in the paper.
\end{abstract}

\section{Introduction}

At present, the state has promulgated the relevant policies about accelerating the development of vocational education and leading some local colleges and universities transformation to the technical applied undergraduate universities . Under these policy guidelines, there are more than six hundred local undergraduate colleges and universities who have joined the tide. Hefei College, Changshu Institute of Technology, and other are the advanced model of successful transformation. It was proved from the theory and practice that transformational development was in line with the law of higher education classification and was consistent with the current situation of domestic economic development, but also was the only way for local colleges and universities to base itself upon, to promote the connotation and to pursue higher development[1]. The sages said: "idea is the basis for action, idea is the leader." Transformation work can not be separated from the participation of society, local colleges and universities, students. The first condition of transformation success is that the local colleges need to change ideas as soon as possible, understand the current society situation, define a clear goal and further promote the development of the colleges with the help of the relevant policies of the country.

\section{Local colleges and universities should change ideas, enhance the connation and then promote the school development with the help of transformation development}

Now most of the local undergraduate colleges and universities in China face a situation that the school-running history is short, the school-running experience is insufficient and the school-running mode is not rich. In the recent years, the low employment rate, the low job suited rate, and the low quality of employment are very common. Local colleges and universities have many difficulties to overcome to develop further. Local colleges and universities should make it clear to themselves that the potential students will become less, the recruitment will be difficult and the students will have great difficulty in hunting a job in the near future. Therefore local colleges and universities must clearly know their position and think about how to develop with the help of the opportunity of national higher education reform. The colleges must enhance the connation, improve the teaching quality and search for the new breakthroughs in order to develop further on the basis of transformational development[2]. For smooth transformation, the first thing that need to do is change the 
thoughts and ideas of the local undergraduate colleges and universities. These colleges and universities can not be developed in accordance with old model. They must realize the importance and urgency of the transformation and realize the difficult situation that they will face. Local colleges and universities need to get rid of the outdated school-running patterns and develop the schools with the new mode, such as the integration of the production and the education as well as the universityenterprise cooperation, which have been proved to be excellent method.

University takes talent cultivation as the target. Local colleges and universities as the main parts of higher education in our country take the main responsible for the service places by cultivating strong capability and high-quality talents. But now the local colleges often copied the schoolrunning models of the national key universities and the veteran elite school who took the academic research in the first place, and were in line with the 211, 985 colleges and universities in the professional setting, personnel training objectives, school orientation and other[3]. There are no clear position, nor its own characteristics for the local colleges and universities, so that the situation has seriously hampered the development of school. Local colleges and universities should change the concept of running-school and put their own development in the service of local economic development. In order to develop the local economy, local colleges and universities should cultivate high-quality and strong application-oriented talents, should contact their own development and local development together[4]. Through school-enterprise cooperation mode, local colleges and universities should play the role of higher education platform and take efforts in establishing the teaching mechanism under the new situation, building their own specialty, combining teaching and research in the production, scientific research application, the students' professional skills training. Meanwhile, the schools should build practice training base with the help of the government and enterprises. In combination with local characteristics of regional economic development, the schools should enhance the ability to serve the local economy by the way of transformation. By serving the local economy, local colleges and universities must ensure the formation of school characteristics as well as improvement of school-running quality and the student employment rate.

\section{College students should change their ideas and establish the correct concept of talent and em- ployment}

Students are the subject of education. Our current education mode has transformed form elite education to mass education, the purpose of education also has transformed from cultivating social elite to cultivating technical elite, so as to improve students' ability to adapt to society. With the expansion of college enrollment, now about $28 \%$ of young people have entered the university, especially most of who enter the local undergraduate colleges and universities. The number of college graduates is increasing year by year ( Figure1 ) .But most disappointing of all, the graduate employment rate is not correspondingly increased in recent years, on the contrary slightly down ( Figure2 ) .A large proportion of the students did not find a satisfactory job because of undergraduate education, and even some people were "graduate that is unemployed". The reason was that there was no direct contact between the students' knowledge and social needs. It looked as though that the society did not need to be a graduate of this sort.

At present, one of the purposes of the transformational development of local undergraduate colleges and universities is to solve the problem of employment of this kind of students. For a local college students, it should be clear for the current social employment difficulties. According to own characteristics, they should change their ideas and establish a correct view of talent and employment. The students should transform the traditional ideas, correct view of talent cultivation, that is “ occupation without distinction”, please don't take the academic research as the only path to themselves. They should accord with their actual situation choose their own way of life. For most people, due to their own qualities, hobbies and other aspects of the reason are not necessarily suitable for academic research. On the contrary, it is more suited than their own development that they em- 
bark on the production line and then become a highly qualified technical personnel ${ }^{[2]}$; secondly, students should should correctly understand why the schools must transform to the technical applied undergraduate universities, the ultimate goal is to improve students' employment skills and develop students' practical skills so that students can find a suitable job in the society. Students should be combined with their own situation, take the initiative to cooperate with the school teaching reform, improve own skills, and better play own talents in the jobs in the future; Finally, now a shortage of highly educated technical talent community is an indisputable fact, students must have a correct employment view and should not blindly pursue unrealistic goals. Students should study hard to master the practical skills in the University that business needs. Once they go out of school, entering the factory to be a high level of highly educated technical personnel also is a way to achieve the self-value and goals of life.

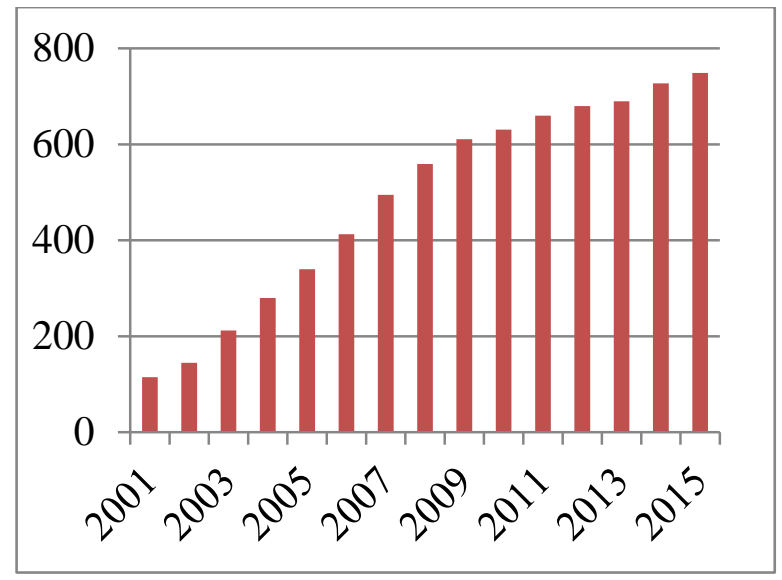

Figure1. The number of college graduates over the years (the unit of vertical axis : ten thousand)

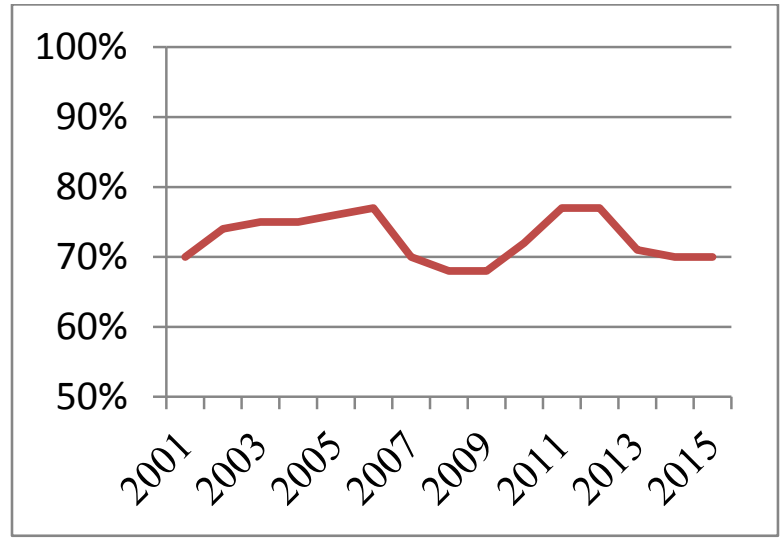

Figure2.The employment rate of college graduates over the years

\section{All social parts should change their ideas and rationally treat universities transformation}

Local governments, local enterprises and students' parents should treat the transformational development situation of local colleges and universities rationally, and do their best to offer help to the transformation and development of colleges and universities. Local governments should play an important role in macro-regulatory functions, at the same time strengthen communication between schools and enterprises through policy guidance, financial support and other measures[5]. As the coordinator between schools and enterprises, local governments are supposed to promote the school-enterprise cooperation in order to enhance their own development. In addition, good environment provided by the local governments can feed the local economy, and improve the ocal economy developing rapidly. Science and technology is the first productive force in modern society, local enterprises should take full advantage of that, change their old thoughts. They should realize that they have the natural advantages of cooperation with local undergraduate colleges. If they co- 
operate with local colleges and universities actively, they can get the benefits from this. On the one hand, they construct a CEEUSRO cooperation and communication platform that can optimize the industrial structure through the transformation of scientific research achievements, and enhance the competitiveness of enterprises[6]; On the other hand, implementing the school-enterprise cooperation that the enterprises build the production practice skills training base, and the schools have its own strong education function can cultivate a large number of high quality and qualified talents for enterprises, and improve the competitiveness and creativity of enterprise employees. Students' parents should change the traditional ideas, have a clear view of occupation education. They should not have a personal witness to the local colleges and universities transformation to technical applied undergraduate universities, and they must realize that vocational education is also an effective way of talent for children, encourage students to choose suitable occupation to enforce their values.

Under the background of the transformation of local undergraduate colleges and universities, the society, schools and students should discard the old unrealistic ideas and clearly recognize the importance of transformation. It may be the most important means to solve the problem of students' employment difficulties and enterprises lack of high technical talents that local colleges and universities transform into the technical applied universities. It is the only way for the transformation of colleges and universities that linking the development of the University and serving the local economy. At the same time, the transformation of local undergraduate colleges and universities should be strongly supported by all social parts. Only the successful transformation of local undergraduate colleges and universities, can the employment rate of students be improved and the local economy gets better development.

\section{References}

[1] Ye Cao. On the transformation and development of regional colleges and universities[J], Journal of Hebei Normal University, 2015 (1)62-66.

[2] Jinrui Chen,Several Speculation on Transformation Development of Newly-founded Undergraduate university[J], Journal of Nanping Teachers College. 2015 (33).

[3] PingWu. Building Modern Vocational Education System and Accelerating Modern Vocational Education Development[J]. Liaoning Higher Vocational Technical Institute Journal. 2015(6)3-6.

[4] Yun Xu. Rational reflection on applied talents cultivation of new undergraduate universities and colleges under the transformation background[J]. Journal of XinYu College, 2015 (2).

[5] Peixin Shi ,On the Reconstruction of Partnership between Local Government and Local Universities[J], Journal of the Qiannan Normal College for Nationalities, 2014 (6).

[6] Jerry G. Gaff,Ronald D. Simpson. Faculty development in the United States[J]. Innovative High er Education , 1994 (3)167-176. 